\title{
Studi Pengembangan Ekonomi Lokal Kota Bogor Berbasis Produk Unggulan Daerah Dengan Analisis SWOT
}

\author{
Kuswadi Rustam ${ }^{1)}$, Rachmat Subarkah ${ }^{2)}$ \\ ${ }^{1}$ Prodi Andministrasi Bisnis Politeknik Sawunggalih Aji, Kutoarjo Purworejo \\ email: kuswadi@polsa.ac.id \\ ${ }^{2}$ Prodi Administrasi Perkantoran Politeknik Muhammadiyah Magelang \\ email: r_subarkah@pmm.ac.id
}

\begin{abstract}
The manufacturing industry contributed 19\% to the GRDP in 2010 - 2017 the second largest after the trade and retail sector, this reflects the city of Bogor as a tourism area and residential area because it is the largest GRDP of the four sectors. Thus, local economic development planning focuses more on the processing industry. the processing industry, which is indeed mostly processed products typical of the city of Bogor with commodities obtained from the FGD results, including typical culinary delights, processed foods, fashion, footwear, and handicrafts. Local Economic Development is expected to not only solve economic problems, but also other aspects of development, namely improving the quality of development and improving local communities. Therefore, through a study of local economic development in Bagor City based on Regional Leading Products with the PUD assessment method based on twelve indicators and a SWOT analysis with the aim of finding superior local economic products and determining a strategy for developing the Local Economy. This research approach uses a questionnaire, primary and secondary data collection, through interviews, qualitative (but still measurable), document study, and Focus Group Discussion (FGD). The city of Bogor has great local economic potential that is able to have a big impact on the regional economy. There are five industries that have the potential to be used as a foundation for local economic development, namely 1. culinary specialties with ungkep chicken commodity; 2. fashion with clothing commodities; 3. crafts with metal craft commodities; 4. batik craft with batik commodities; and 5. rubber with footwear commodities. The results of the Klassen typology calculation that have been carried out state that the processed industrial sector in the city of Bogor in which there are five local commodities in the city of Bogor is included in a sector that has the potential to be developed because it has great potential to be developed, and is not a regional base sector. . There are 15 strategies for developing local economic commodities, namely 1. Development of production capacity; 2. Development of production quality and technology; 3. Development of access to capital; 4. HR development; 5. Build branding; 6. Business Expansion; 7. Development of production technology efficiency; 8. Development of business licensing services; 9. Development of promotional facilities and marketing networks; 10. Optimization of business area; 11. Infrastructure development, especially transportation and road network; 12.
\end{abstract}


Development of business competitiveness; 13. Business Strengthening; 14. Entrepreneurship development; and 15. Business assistance..

Keywords: local,economic,swot,study

\section{A. PENDAHULUAN}

Pertumbuhan ekonomi yang pesat pada saat ini sangat diperlukan bagi pembangunan kota. Masalah-masalah yang melekat dalam pembangunan kota seperti melimpahnya angkatan kerja, sedikitnya lapangan kerja, dan menjamurnya kemiskinan menjadi faktor pendorong untuk melaksanakan percepatan pembangunan ekonomi di daerah. Walau demikian, tidak selalu pertumbuhan ekonomi akan mampu menjadi strategi yang mampu mengatasi masalah-masalah klasik di atas. Pertumbuhan ekonomi yang mengandalkan potensi dan sumber daya yang berasal dari luar (exogenous) terlihat positif bagi pertumbuhan ekonomi, namun sebenarnya tidak menciptakan dampak bagi kemandirian dan ketahanan ekonomi daerah secara mendasar.

Salah satu upaya untuk menciptakan kemandirian dan ketahanan ekonomi daerah adalah melalui peningkatan daya saing daerah. Pencapaian keunggulan daya saing suatu daerah dapat diupayakan salah satunya melalui pengembangan ekonomi lokal. Melalui perhatian terhadap ekonomi lokal diharapkan daerah mampu mengidentifikasi produk-produk unggulan dan menemukan beberapa strategi yang menunjang untuk menciptakan iklim unggulan di daerah. Dengan demikian Informasi produk unggulan dan potensi ekonomi suatu daerah dapat menciptakan sentra-sentra usaha unggulan atau suatu produk yang akhirnya menjadi produk unggulan.

Ekonomi lokal merupakan salah satu strategi yang dianggap sebagai langkah yang tepat untuk menciptakan pertumbuhan ekonomi, dan pada saat yang sama mampu mendorong kemandirian dan ketahanan ekonomi. Disisi lain usaha kecil dan menengah (UKM) sejauh ini dianggap sebagai instrumen yang penting dalammenciptakan lapangan kerja. UKM terdiri dari para pengusaha mikro dari petani, pedagang hingga pabrikan lokal yang merupakan inti pembangunan ekonomi lokal.

Kota Bogor sebagai salah satu kota yang menjadi penyangga ibukota Jakarta, memiliki keragaman sektor usaha. Kota Bogor sebagai kota yang kontribusi utamanya dari sektor jasa perlu menganalisa hal ini lebih lanjut sehingga diketahui usaha apa saja yang merupakan potensi ekonomi lokal yang bila dikembangkan akan berdampak sistemik kepada peningkatan kesejahteraan masyarakat lokal. Pengembangan ekonomi lokal diharapkan tidak hanya mampu memecahkan permasalahan ekonomi, tetapi juga aspek pembangunan lainnya yaitu peningkatan kualitas pembangunan dan perbaikan pada komunitas lokal dalam bentuk pengurangan tingkat kemiskinan, peningkatan kemandirian dan pemenuhan kebutuhan dasar manusia serta peningkatan daya saing daerah. oleh karena itu dilaksanakan penelitian "Studi pengembangan ekonomi lokal Kota Bogor berbasis Produk Unggulan Daerah dengan analisis SWOT". Penelitian ini 
bertujuan untuk menganalisis potensi ekonomi lokal Kota bogor terhadap peningkatan ekonomi masyarakat sekitar dan menemukan beberapa strategi pengembangannya.

\section{B. KAJIAN LITERATUR DAN TEORI}

Menurut Blakely (2002) komponen dalamPengembangan Ekonomi Lokal ini antara lainmaterial, Sumber Daya Manusia, pasar,manajemen, dan modal. Material yangdimaksud dalam hal ini adalah mencakup Sumber DayaAlam

Menurut Niskha Sandriana, Abdul Hakim, Choirul Saleh (2015) secara umum bahwa kriteria penentuan produk unggulan daerah berbasis klaster di Kota Malang adalah: Produk unik/khas/trade mark daerah; Sumbangan terhadap perekonomian daerah; Pasar; Kondisi input (ketersediaan infrastruktur, SDM, teknologi, modal); Kemitraan; Dukungan kebijakan dan kelembagaan; Dampak terhadap lingkungan; Tingkat daya saing.

Berdasarkan data BPS, 2018, umumnya dengan melihat data PDRB dapat memperhitungkan kesejahteraan penduduk di suatu wilayah, dan dengan data PDRB itu pula seseorang dapat melihat kemajuan suatu wilayah. Rata-rata kontribusi sektoralPDRB Kota Bogor tahun 2010 - 2017 memperlihatkan pembentukan PDRB terbesar terdiri atas sektor industri pengolahan, sektor perdagangan dan eceran, Sektor Pergudangan Transportasi dan sektor kontruksi membentuk lebih dari 50 persen PDRB Kota Bogor $(19+22+11+12=64$ persen $)$. Industri pengolahan menyumbangkan 19 persen PDRB tahun 2010 - 2017 terbesar kedua setelah sektor perdagangan dan eceran, hal ini mencerminkan kota bogor sabagai kawasan pariwisata dan kawasan hunian karena pembentuk PDRB terbesar dari ke empat sektor tersebut. Oleh karena itu, sangatlah beralasan jika ke empat sektor tersebut perlu perhatian khusus dari pemerintah Kota Bogor agar dapat di kembangkan dengan tanpa mengesampingkan sektor yang lainya. Dengan demikian, strategi pengembangan ekonomi lokal berfokus pada industri pengolahan yang memang sebagian besar merupakan hasil olahan khas Kota Bogor

Menurut Permendagri No. 9 Tahun 2014, Produk Unggulan Daerah yang selanjutnya disingkat PUD merupakan produk, baik berupa barang maupun jasa, yang dihasilkan oleh koperasi, usaha skala kecil dan menengah yang potensial untuk dikembangkan dengan memanfaatkan semua sumberdaya yang dimiliki oleh daerah baik sumberdaya alam, sumberdaya manusia dan budaya lokal, serta mendatangkan pendapatan bagi masyarakat maupun pemerintah yang diharapkan menjadi kekuatan ekonomi bagi daerah dan masyarakat setempat sebagai produk yang potensial memiliki daya saing, daya jual, dan daya dorong menuju dan mampu memasuki pasar global. Pemerintah daerah berwenang menyusun dan menetapkan PUD setiap tahun sesuai dengan kriteria indikator PUD antara lain:

1. Penyerapan tenaga kerja. PUD diproduksi dengan memanfaatkan tenaga kerja terampil di daerah yang bersangkutan sehingga memberi dampak pada penciptaan lapangan kerja dan pendapatan bagi masyarakat setempat. 
2. Sumbangan terhadap perekonomian. PUD merupakan produk yang memiliki nilai ekonomis, memberikan manfaat bagi konsumen, memiliki keterkaitan ke depan dan ke belakang, memberi efek berganda ekonomi dan sekaligus memberikan keuntungan ekonomi bagi seluruh pemangku kepentingan dan daerah yang memproduksi produk tersebut.

3. Sektor basis ekonomi daerah. PUD merupakan produk yang masuk dalam kategori kelompok sektor basis dalam PDRB dan memberikan kontribusi terbesar dalam ekonomi daerah.

4. Dapat diperbaharui. PUD bukan barang tambang dan memanfaatkan bahan baku yang dapat diperbaharui dan ramah lingkungan. Barang tambang tidak dapat dimasukkan sebagai PUD meskipun saat itu memberi kontribusi ekonomi yang besar bagi daerah.

5. Sosial budaya. Unsur sosial budaya dalam menciptakan, memproduksi dan mengembangkan PUD adalah menggunakan talenta dan kelembagaan masyarakat yang dibangun dan dikembangkan atas dasar kearifan lokal yang bersumber pada ciri khas dan warisan budaya turun-temurun serta kondisi sosial budaya setempat.

6. Ketersediaan pasar. Ketersediaan pasar adalah kemampuan PUD untuk terserap pada pasar lokal, regional dan nasional serta berpotensi untuk memasuki pasar global.

7. Bahan baku. Bahan baku PUD terjamin ketersediaannya dengan harga yang kompetitif, terjamin kesinambungannya serta ramah lingkungan.

8. Modal. Modal adalah ketersediaan dan kecukupan dana bagi kelancaran usaha untuk kebutuhan investasi dan modal kerja.

9. Sarana dan prasarana produksi. Sarana dan prasarana produksi adalah kemudahan bagi pengusaha PUD untuk memperoleh sarana dan prasarana produksi pada tingkat harga yang kompetitif dan mudah diperoleh.

10. Teknologi. PUD diproduksi dengan teknologi yang relevan, tepat guna dan terdapat unsur yang tidak mudah ditiru.

11. Manajemen usaha. Manajemen usaha merupakan kemampuan mengelola usaha secara profesional dengan memanfaatkan talenta dan kelembagaan masyarakat.

12. Harga. Harga merupakan kemampuan memberi nilai tambah dan mendatangkan laba usaha.

\section{METODA PENELITIAN}

\section{Pendekatan Penelitian}

Pendekatan yang dilakukan dalam penelitian ini adalah dengan melakukan pengumpulan data di lapangan melalui data primer maupun sekunder, yang diperoleh melalui penyebaran kuesioner, wawancara dengan pendekatan dan kuantitatif dan 
kualitatif (namun tetap terukur), melalui studi dokumen, dan Focus Group Discussion (FGD).

\section{Lokasi dan Obyek Penelitian}

Lokasi penelitian di wilayah Kota Bogor dengan obyek industri pengolahan yang memang sebagian besar merupakan hasil olahan khas Kota Bogor, dengan komoditas yang diperoleh dari hasil FGD antara lain kuliner khas, olahan pangan, fesyen, alas kaki, dan kerajinan.

\section{Instrumen Penelitian}

Instrumen penelitian menggunakan kuesioner sesuai Permendagri No. 9 Tahun 2014, Produk Unggulan Daerah yang selanjutnya disingkat PUD yang didasarkan pada penilaian PUD melalui dua belas indikator kiriteria PUD.

\section{Teknik Analisis Data}

Analisis data menggunakan penilaian PUD yang didasarkan pada dua belas indikator dengan cara :

1. Menghitung skor komoditas berdasarkan dua belas kriteria;

2. Menghitung bobot kriteria dari kedua belas kriteria PUD berdasarkan tingkat kepentingannya;

3. Menghitung skor akhir komoditas PUD.

Analisis matriks SWOT dengan membandingkan secara sistematis hasil kekuatan dan kelemahan dari lingkungan internal dengan peluang dan ancaman dari lingkungan eksternal untuk menghasilkan kombinasi strategi dari masing komoditas terpilih

\section{HASIL DAN PEMBAHASAN}

Kota Bogor mempunyai potensi ekonomi lokal yang besar yang mampu memberikan dampak yang besar bagi perekonomian daerah karena mampu mendorong perekonomian masyarakat hingga lapisan paling bawah, hal ini terlihat dari hasil analisis dan pembahasan ssb:

1. Kuliner Khas

\subsection{Ayam Ungkep}

1. Penyerapan Tenaga Kerja

Penyerapan tenagakKerja pada sektor ini tidak terlalu tinggi karena sebagaian besar proses produksi secara tradisonal atau masih bersifat home industri, sehingga proses produksi di lakukan oleh anggota keluarga mereka.

2. Sumbangan terhadap perekonomian

Sektor industri makanan olahan ini menyumbangkan $19 \%$ dalam 
pembentukan PDRB dari sektor Industri olahan. Sementara sub sektor industri olahan makanan memberikan kontribusi $19 \%$ pada sektor sektor industri olahan

3. Sektor basis ekonomi daerah

Sektor ini termasuk kedalam sektor yang potensial untuk di kembangkan karena mempunyai potensi yang besar untuk di kembangkan, dan bukan merupakan sektor basis Daerah.

4. Dapat diperbaharui

Ayam ungkep merupakan produk olahan makanan yang dapat di perbaharui (bukan merupakan bahan Tambang) karena mempunyai jaringan suplay chan yang kesemuanya dapat di perbaharui. Bahan baku yang digunakan adalah ayam potong yang di dapat dari hasil peternakan, di mana kesedian bahan baku tersedia sepanjang tahun tanpa terpengaruhi oleh musim dan stok yang habis karena di gunakan seperti hasil tambang. Sedangkan bahan baku sekunder berupa hasil pertanian yaitu bumbu bumbu dapur yang juga mudah di dapat di Pasar - Pasar lokal.

5. Unsur sosial budaya

Ayam ungkep merupakan kuliner khas Kota Bogor yang berkembang dengan pesat di tenggah masyarakat dan merupakan warisan budaya lokal karena mempunyai cita rasa yang khas dan identik dengan Kota Bogor. Kuliner ini berkembang di Kecamatan Tanah Sareal yang secara spesifik di Kelurahan Cibdak, bahkan di Desa Pabuaran sebagaian besar masyarakatnya (70 \%) merupakan produsen ayam ungkep ini.

6. Ketersediaan pasar

Dengan berkembangnya Kota Bogor sebagai tujuan wisata dan kota pendidikan maka potensi pasar kuliner ini juga akan semakin besar, ayam ungkep ini juga berpotensi untuk menjadi ikon oleh - oleh khas Kota Bogor selain talas. Selain karena faktor tersebut Kota Bgor sebagai penyangga ibu kota dimana populasi penduduknya semakin meningkat dari tahun ke tahun menjadi potensi pasar besar bagi kuliner ini. Namun karena terkendala faktor perizinan no PIRT dan Higent sanitasi dari dinas kesahatan yang mensayarakan adanya Nomor Induk Berusaha (NIB) maka ini menjadi kendala pengusaha untuk menembus pasar yang lebih luas dan besar.

7. Ketersedian bahan baku

Ayam potong merupakan bahan utama dari produk ini dan ketersedian di pasar atau rumah potong ungkas cukup besar dan terjamin ketersedianya di sepanjang tahun.

8. Modal

Dari hasil survai yang di lakukan dapat di simpulkan sebagaian besar permodalan dalam usaha ini berasal dari modal sendiri.

9. Sarana dan prasarana produksi 
Proses Produksi ayam ungkep ini tidak jauh dari proses memasak pada umumnya sehingga peralatan yang di gunaan sama dengan proses memasak secara umumnya sehingga sarana dan prasaranya juga sama seperti wajan, panic, ulekan, serok, sothel, dll. Karena proses produksi ini rumahan dan bergabung dengan dapur rumah tangga maka proses sanitasi belum berjalan dengan baik, baik untuk system air bersih ataupun system pembuangan limbah produksi, maka kebanyakan rumah produksi ini belum mendapatkan no PIRT ataupun sertikat hignt dan sanitasi dari dinas kesehatan. Ada baiknya bila ada pendampingan untuk mendapatkan sertifikat tersebut sehingga produk yang di hasilkan layak untuk di konsumsi dengan izin dari pemerintah, sehinnngga di kemudian hari tidak di salahkan.

10. Teknologi

Di dalam rumah produksi ayam ungkep ini belum mengunakan pendekatan teknologi produksi yang modern dan sistematis masih mengunakan teknologi tradisonal yang turun temurun kecuali pada hal pengapian, jika dahulu proses pengapian mengunakan tungku maka sekarang sudah mengunakan kompor gas sehingga api lebih stabil.

11. Manajemen Usaha

Jika di tinjau dari segi manajemen pengolahan rumah produksi ini juga masih di jalankan secara tradisonal karena baik pengohan produksinya ataupun pengolahan managemen usashanya masih belum berjalan dengan baik karena masih bergabung dengan managemen keluarga karena usaha ini juga sebagian menjadi pemopang keluarga sehinga berlum terpisah untuk pembukuan keuangan, asset, dan cash flow keuangan harianya.

\section{Harga}

Sebagian produk ayam ungkep ini tergolong kompetitif dengan produk ayam sejenis karena di jual dengan harga yang tidak jauh dari harga pasaranya, untuk ayam potong ungkep di jual kisaran harga 7.000-20.000 sedangkan untuk ayam ungkep untuk di jual kisaran 50.000 sampai 100.000 .

2. Fasyen

\subsection{Pakaian}

1. Penyerapan Tenaga Kerja

Penyerapan tenaga kerja pada industripakaian ini cukup tinggi karean rata - rata tenaga kerja yang dapat terserap 3-7 orang . per rumah produksi pakaian, sedangkan jumlah rumah produksi pakaian di kota bogor jumlahnya banyak, maka jumlah tenaga kerja yang terserap pada sector ini begitu tinggi hal ini dapat di lihat dari sumbangan sector ini pada pembentuk PDRB sector industry olahan yang mencapai angka $42 \%$,

2. Sumbangan terhadap perekonomian

Sumbangan sub sektor industri pakaian memberikan kontribusi $42 \%$ 
pada sektor Sektor industri pakaian

3. Sektor basis ekonomi daerah

Hasil perhitungan yang telah di lakukan di atas menyatakan bahwa sektor industri olahan yang ada di kota bogor termasuk kedalam sektor yang potensial untuk di kembangkan karena mempunyai potensi yang besar untuk di kembangkan, dan bukan merupakan sektor basis daerah.

4. Dapat diperbaharui

Industri pakaian merupakan industri yang dapat di perbaharuhi (Non hasil tambang) karena bahan utama dari produksi ini adalah kain yang merupakan produk dari industry olahan juga sehingga ketersedian akan bahan baku akan terjamin ada di pasaran.

5. Unsur sosial budaya

Kota Bogor tidak hanya merupakan kota tujuan wisata dan pendidikan akan tetapi juga sebagai kota fasyen sama seperti Kota Bandung, fasyen tidak hanya sebagai industri saja akan tetapi juga telah menjadi budaya lokal yang tumbuh seiring dengan tumbuhnya kreativitas pengiat usaha ini sehngga banyak tren dan mode yang tumbuh dari Kota Bogor. Selain itu karena permintaan akan kebutuhan fasyen ini yang tinggi maka usaha ini juga meninglat produksinya.

6. Ketersediaan pasar

Dengan berkembangnya Kota Bogor sebagai tujuan wisata dan kota pendidikan , kota fasyen maka potensi pasar yang besar Karena banyaknya orang yang berkunjung di kota ini baik sebagai wisatawan ataupun sebagai mahasiswa. Selain itu potensi besar juga dating dari lokal Kota Bgor yang jumlah penduduknya meningkat terus dari tahun ke tahun merupakan pangsa pasar yang besar untuk memenuhi kebutuhan akan fasyen itu sendiri.

7. Ketersedian bahan baku

Kain sebagai bahan dasar pembuatan fasyen ini akan selalu ada selama industry olahan tekstil masih ada, sehingga keterjaminan bahan baku terjamin keberadaanya.

8. Modal

Dari hasil survai yang di lakukan dapat di simpulkan sebagaian besar permodalan dalam usaha ini berasal dari modal sendiri.

9. Sarana dan prasarana produksi

Di dalam proses produksi fasyen ini belum banyak teknologi peralatan ataupun system produksi yang di adobsi, system produksi maupun alur produksi dalam proses produksi ini masih mengunakan cara yang tradisonal secara umumnya di industry fasyen tradisional dimana proses pembentukan pola, cutting, jahit dan swawing di lakukan secara tradisonal dan job sop dimana orang / tenaga kerja akan memualai prosenya dengan membentuk pola sendiri kemudian cutting dan memindahkanya 
ke jahit kemudian finisihing / swawing secara berkala dan belum terbentuk struktur yang baku, sehingga produktivitasnya menjadi terbatas.

10. Teknologi

Di dalam rumah produksi fasyen ini belum banyak teknologi yang di adobsi baik dari system produksinya ataupun alur produksinya, sehingga produsktivitasnya belum begitu tinggi.

11. Manajemen Usaha

Jika di tinjau dari segi manajemen pengolahan rumah produksi ini juga masih di jalankan secara tradisonal karena baik pengohan produksinya ataupun pengolahan managemen usashanya masih belum berjalan dengan baik karena masih bergabung dengan managemen keluarga karena usaha ini juga sebagian menjadi penopang keluarga sehinga belum terpisah untuk pembukuan keuangan, asset, dan cash flow keuangan harianya.

12. Harga

Untuk segi harga, sebagian produk yang di hasilkan dari rumah produksi ini cukup bersaing dengan komoditas yang sama di pasaran tergantung

3. Kerajianan dengan model, bahan dan tingkat kesulitan dalam proses pengerjaanya.

\subsection{Kerajinan Logam}

1. Penyerapan tenaga kerja

Penyerapan tenaga kerja pada sektor ini tidak terlalu tinggi karena sebagaian besar proses produksi secara tradisonal atau masih bersifat home industri, sehingga proses produksi di lakukan secara manual dan tradisional

2. Sumbangan terhadap perekonomian

Sumbangan sektor industri barang logam ini menyumbangkan $2 \%$ dalam pembentukan PDRB dari sektor Industri Olahan. Sementara sub sektor industri barang logam memberikan kontribusi juga 2\% pada sektor barang logam

3. Sektor basis ekonomi daerah

Hasil Perhitungan yang telah di lakukan di atas menyatakan bahwa sektor industri olahan yang ada di kota bogor termasuk kedalam sektor yang potensial untuk di kembangkan karena mempunyai potensi yang besar untuk di kembangkan, dan bukan merupakan sektor basis Daerah

4. Dapat diperbaharui

Usaha produksi barang logam ini mempunyai jaringan supplay - chain yang agak rumit dimana ketergantungan bahan terhadap seng bekas drum agak tinggi sehingga agak berisiko jika sudah tidak ada lagi seng bekas sebagai bahan utama proses produksi ini. Produk ini merupakan produk yang dapat di perbaharui karena bukan barang hasil pertambang.

5. Unsur sosial budaya

Kerajianan barang logam yang ada di Kota Bogor merupakan hasil 
kreasi budaya lokal hal ini dapat di lihat dari proses produksinya yang berbeda dengan proses produksi di daerah lainya, jika proses industri olahan logam/almunium di tempat lain mengunakan sistem pengejoran logam, di mana logam di panaskan terlebih dahulu hingga menjadi bubur logam kemudian di tuangkan kedalam cetakan dan di tunggu hingga dingin kemudian baru di amplas/penghalusan. Sedangkan di Kota Bogor pengelolaan industri barang logam ini dibuat dengan sistem di tempa, seng bekas drum di buat pola kemudian di potong dan digabung dangan potongan yang lainya kemudian di bentuk dengan proses tempa, dan finishing dengan proses amplas. Dari segi bahan baku dan proses produksinya mencerminkan budaya lokal yang kuat.

6. Ketersediaan pasar

Pasar industri ini masih terus ada selama kebutuhan akan peralatan memasak ada, penyedian makanan, dan yang membutuhkan barang kerjinan logam ini, pasar produk ini juga terbentak lebar jika mampu masuk pasar - pasar di DKI. Jakarta.

7. Ketersedian bahan baku

Bahan Utama produksi barang logam ini adalah seng bekas drum, ketergantungan bahan baku terhadap produk terhadap produk yang lainya sangat besar, jika produk tersebut berhenti mengunakan seng, maka kalau tidak berubah bahan bakunya maka kelanjutan usaha ini akan terancam juga.

8. Modal

Dari hasil survai yang di lakukan dapat di simpulkan sebagaian besar permodalan dalam usaha ini berasal dari modal sendiri.

9. Sarana dan prasarana produksi

Proses produksi pada industri barang logam ini masih begitu sederhana sehingga peralatan yang di gunakan juga tak begitu rumit dan mudah di temukan. .

10. Teknologi

Di dalam industri barang logam ini belum mengunakan pendekatan teknologi produksi yang modern dan sistematis masih mengunakan teknologi tradisonal yang turun temurun dengan pengunaan sistem tempa,

11. Manajemen usaha

Jika di tinjau dari segi manajemen pengolahan rumah produksi ini juga masih di jalankan secara tradisonal karena baik pengolahan produksinya ataupun pengolahan managemen usashanya masih belum berjalan dengan baik karena masih bergabung dengan managemen keluarga karena usaha ini juga sebagian menjadi pemopang keluarga sehinga berlum terpisah untuk pembukuan keuangan, asset, dan cash flow keuangan harianya.

12. Harga

Untuk segi harga, sebagian produk ini tergolong kompetitif dengan produk 
4. Kerajinan Batik

ayam sejenis karena di jual dengan harga yang tidak jauh dari harga pasaranya,

4.1.Kerajinan Batik

1. Penyerapan tenaga kerja

Penyerapan tenaga kerja pada sektor ini belum begitu tinggi karena sistem pengerjaan batik ini dengan sistem kelompok, dari 1 kelompok tersebut terdapat 4-6 pembatik, sedangkan di daerah kelurahan cibuluh terdapat 4 kelompok dengan 25 pengrajin batik.

2. Sumbangan terhadap perekonomian

Sektor industri tekstil dan pakaian ini menyumbangkan $42 \%$ dalam pembentukan PDRB dari sektor Industri Olahan. Sub sektor industri barang logam memberikan kontribusi $42 \%$ pada sektor barang tekstil dan pakaian

3. Sktor basis ekonomi daerah

Hasil Perhitungan yang telah di lakukan di atas menyatakan bahwa sektor industri olahan yang ada di Kota Bogor termasuk kedalam sektor yang potensial untuk di kembangkan karena mempunyai potensi yang besar untuk di kembangkan, dan bukan merupakan sektor basis daerah

4. Dapat diperbaharui

Industri batik merupakan industry yang dapat di perbaharuhi (Non hasil Tambang) karena bahan utama dari produksi ini adalah kain yang merupakan produk dari industry olahan juga sehingga ketersedian akan bahan baku akan terjamin ada di pasaran.

5. Unsur sosial budaya

Biarpun Batik Bogor bukan merupakan budaya lokal asli Kota Bogor akan tetapi dengan perkembanganya di kota bogor yang mampu di terima di masyarakat dan kalangan sekitar, maka Pemerintah Kota Bogor telah mencetuskan batik yang identik dengan Kota bogor yang diberi nama Batik Bogor dan sekarang akan di kembangan Kampung Batik Bogor

6. Ketersediaan pasar

Dengan berkembangnya kota bogor sebagai tujuan wisata dan kota pendidikan, kota fasyen maka potensi pasar yang besar Karen banyaknya orang yang berkunjung di kota bogor ini baik sebagai wisatawan ataupun sebagai mahasiswa. Selain itu potensi besar juga dating dari lokal Kota Bogor yang jumlah penduduknya meningkat terus dari tahun ke tahun merupakan pangsa pasar yang besar untuk memenuhi kebutuhan sendiri.

7. Ketersedian bahan baku

Kain sebagai bahan dasar pembuatan batik ini akan selalu ada selama industry olahan tekstil masih ada, sehingga keterjaminan bahan baku terjamin keberadaanya.

8. Modal 
Dari hasil survai yang di lakukan dapat di simpulkan sebagaian besar permodalan dalam usaha ini berasal dari modal sendiri.

9. Sarana dan prasarana produksi

Di dalam proses produksi batik ini masih mengunakan batik tulis di mana batik di gambar dengan pola - pola tertentu dengan mengunakan malam, kemudian masuk proses pewarnaan. Dalam proses pewarnaan inil belum begitu baik sehingga masih perlu pendampingan dan training.

10. Teknologi

Di dalam rumah produksi belum banyak teknologi yang di adopsi baik dari sistem produksinya ataupun alur produksinya, sehingga produsktivitasnya belum begitu tinggi.

11. Manajemen Usaha

Jika di tinjau dari segi manajemen pengolahan rumah produksi ini juga masih di jalankan secara tradisonal karena baik pengohan produksinya ataupun pengolahan managemen usashanya masih belum berjalan dengan baik karena masih bergabung dengan managemen keluarga karena usaha ini juga sebagian menjadi penopang keluarga sehinga berlum terpisah untuk pembukuan keuangan, asset, dan cash flow keuangan harianya.

12. Harga

Sebagian produk yang di hasilkan dari rumah produksi ini cukup bersaing dengan komoditas yang sama di pasaran tergantung dengan model, bahan dan tingkat kesulitan dalam proses pengerjaanya.

5. Industri Karet

5.1. Alas kaki

1. Penyerapan Tenaga Kerja

Penyerapan tenaga kerja pada sektor ini termasuk tinggi dimana proses pengerjaan alas kaki memerlukan tenaga kerja anatara $3-7$ orang per rumah produksi, sedangkan di Kecamatan Karet sebagai besar pendudukanya adalah pengrajin alas kaki ini.

2. Sumbangan terhadap perekonomian

Sektor industri olahan karet ini menyumbangkan $13 \%$ dalam pembentukan PDRB dari sektor Industri Olahan. Adapun sektor industri olahan karet memberikan kontribusi $13 \%$ pada sektor sektor barang logam tekstil dan pakaian.

3. Sektor basis ekonomi daerah

Hasil Perhitungan yang telah di lakukan di atas menyatakan bahwa sektor industri olahan yang ada di Kota Bogor termasuk kedalam sektor yang potensial untuk di kembangkan karena mempunyai potensi yang besar untuk di kembangkan, dan bukan merupakan sektor basis daerah.

4. Dapat diperbaharui

Industri olahan karet merupakan industry yang dapat di perbaharuhi (Non hasil Tambang) karena bahan utama dari produksi ini adalah karet 
dan busa yang merupakan produk dari industry olahan juga sehingga ketersedian akan bahan baku akan terjamin ada di pasaran.

5. Unsur sosial budaya

Industri olahan karet berkembang dengan pesat di kota bogor dan telah mengakar di masyarakat. Industri alas kaki ini terbentuk karena kreatifitas dan sosial budaya masyarakat kota bogor yang kreatif

6. Ketersediaan pasar

Dengan berkembangnya kota bogor sebagai tujuan wisata dan kota pendidikan, kota fasyen dan alas kaki maka potensi pasar yang besar Karen banyaknya orang yang berkunjung di kota ini baik sebagai wisatawan ataupun sebagai mahasiswa. Selain itu potensi besar juga dating dari lokal Kota Bogor yang jumlah penduduknya meningkat terus dari tahun ke tahun merupakan pangsa pasar yang besar untuk memenuhi kebutuhan akan karet itu sendiri.

7. Ketersedian bahan baku

Karet dan busa sebagai bahan dasar pembuatan alasa kaki ini akan selalu ada selama industry olahan tekstil masih ada, sehingga keterjaminan bahan baku terjamin keberadaanya.

8. Modal

Dari hasil survai yang di lakukan dapat di simpulkan sebagaian besar permodalan dalam usaha ini berasal dari modal sendiri.

9. Sarana dan prasarana produksi

Di dalam proses produksi alas kaki mengunakan perlatan yang masih banyak di gunakan seperti mesin jahit, mesin pres, lem, gunting, dll proses produksi yang masih tradisonal ini membutuhkan pengembangan untu meningkatkan produkstivitas ushanya.

10. Teknologi

Di dalam rumah produksi alas kaki ini belum banyak teknologi yang di adopsi baik dari sistem produksinya ataupun alur produksinya, sehingga produsktivitasnya belum begitu tinggi.

11. Manajemen Usaha

Jika di tinjau dari segi manajemen pengolahan rumah produksi ini juga masih di jalankan secara tradisonal karena baik pengohan produksinya ataupun pengolahan managemen usashanya masih belum berjalan dengan baik karena masih bergabung dengan managemen keluarga karena usaha ini juga sebagian menjadi penopang keluarga sehinga berlum terpisah untuk pembukuan keuangan, asset, dan cash flow keuangan hariannya.

12. harga

Untuk segi harga, sebagian produk yang di hasilkan dari rumah produksi ini cukup bersaing dengan komoditas yang sama di pasaran tergantung dengan model, bahan dan tingkat kesulitan dalam proses pengerjaanya. 
Berdasarkan hasil analisis SWOT terhadap lima komuditas unggulan terpilih diperoleh kombinasi strategi pengembangan sebagaimana tabel berikut :

\section{Kuliner Khas}

Tabel 1.1. Matriks Kombinasi Strategi Komoditas Ayam Ungkep

\begin{tabular}{ll}
\hline \multicolumn{1}{c}{ Kekuatan } & \multicolumn{1}{c}{ Kelemahan } \\
\hline - Sektor basis ekonomi & - Penyerapan tenaga \\
daerah & kerja \\
- Bahan baku & - Sumbangan terhadap \\
& perekonomian \\
& - Dapat diperbaharui \\
& - Sosial budaya \\
& - Manajemen usaha \\
& - Modal \\
& - Teknologi. \\
& - Ketersediaan pasar \\
& - Harga \\
\hline
\end{tabular}

\begin{tabular}{|c|c|c|}
\hline Peluang & $\mathrm{SO}$ & WO \\
\hline $\begin{array}{l}\text { - Letak wilayah Kota } \\
\text { Bogor } \\
\text { - Angkatan kerja } \\
\text { - Pengeluaran per kapita } \\
\text { - Komitmen pemerintah } \\
\text { Kota Bogor } \\
\text { - Kunjungan wisatawan ke } \\
\text { Kota Bogor } \\
\text { - Pelayanan Perijinan }\end{array}$ & $\begin{array}{l}\text { 1.Pengembangan kapasitas } \\
\text { produksi } \\
\text { 2.Pengembangan kualitas } \\
\text { produk } \\
\text { 3.Pengembangan klaster } \\
\text { usaha terutama usaha } \\
\text { sektor basis ekonomi } \\
\text { daerah } \\
\text { 4.Pengembangan hak } \\
\text { paten }\end{array}$ & $\begin{array}{l}\text { 1.Perluasan usaha } \\
\text { 2. Pengembangan } \\
\text { teknologi produksi } \\
\text { 3.Pengembangan akses } \\
\text { permodalan } \\
\text { 4.Pengembangan sdm } \\
\text { 5.Pengembangan sarana } \\
\text { promosi dan jaringan } \\
\text { pemasaran }\end{array}$ \\
\hline Ancaman & ST & WT \\
\hline $\begin{array}{l}\text { - Kepadatan penduduk } \\
\text { - Keterbatasan lahan } \\
\text { - Transportasi } \\
\text { - Jaringan jalan } \\
\text { - Pesaing }\end{array}$ & $\begin{array}{l}\text { 1. Optimalisasi lahan usaha } \\
\text { 2.Pengembangan } \\
\text { infrastruktur terutama } \\
\text { transportasi dan jaringan } \\
\text { jalan } \\
\text { 3.Pengembangan daya } \\
\text { saing usaha. }\end{array}$ & $\begin{array}{l}\text { 1.Penguatan usaha } \\
\text { 2.Pengembangan inovasi } \\
\text { usaha } \\
\text { 3.Pengembangan } \\
\text { kewirausahaan }\end{array}$ \\
\hline
\end{tabular}

Sumber: Data Primer, diolah. 


\section{Fesven}

Tabel 1.2. Matriks Kombinasi Strategi Komoditas Pakaian

\begin{tabular}{|c|c|c|}
\hline & Kekuatan & Kelemahan \\
\hline & $\begin{array}{l}\text { - Bahan Baku } \\
\text { - Modal } \\
\text { - Sarpras Produksi } \\
\text { - Teknologi }\end{array}$ & $\begin{array}{l}\text { - Penyerapan tenaga } \\
\text { kerja } \\
\text { - Sumbangan terhadap } \\
\text { perekonomian } \\
\text { - Sektor basis ekonomi } \\
\text { daerah } \\
\text { - Dapat diperbaharui } \\
\text { - Sosial budaya } \\
\text { - Manajemen usaha } \\
\text { - Ketersediaan pasar } \\
\text { - Harga }\end{array}$ \\
\hline Peluang & $\mathrm{SO}$ & WO \\
\hline $\begin{array}{l}\text { - } \text { Letak wilayah Kota } \\
\text { Bogor } \\
\text { - Angkatan kerja } \\
\text { - Pengeluaran per kapita } \\
\text { - Komitmen pemerintah } \\
\text { Kota Bogor } \\
\text { - Kunjungan wisatawan ke } \\
\text { Kota Bogor } \\
\text { - Pelayanan perijinan }\end{array}$ & $\begin{array}{l}\text { 1.Peningkatan investasi } \\
\text { 2.Pengembangan kapasitas } \\
\text { produksi dengan } \\
\text { penggunaan teknologi } \\
\text { produksi } \\
\text { 3.Pengembangan kualitas } \\
\text { produksi melalui } \\
\text { standarisasi hak paten }\end{array}$ & $\begin{array}{l}\text { 1.Perluasan usaha } \\
\text { 2. Pengembangan } \\
\text { teknologi produksi } \\
\text { 3. Pengembangan } \\
\text { pelayanan perijinan } \\
\text { usaha } \\
\text { 4. Pengembangan SDM } \\
\text { 5. Pengembangan sarana } \\
\text { promosi dan jaringan } \\
\text { pemasaran }\end{array}$ \\
\hline Ancaman & ST & WT \\
\hline $\begin{array}{l}\text { - Kepadatan penduduk } \\
\text { - Keterbatasan lahan } \\
\text { - Transportasi } \\
\text { - Jaringan jalan } \\
\text { - Pesaing }\end{array}$ & $\begin{array}{l}\text { 1. Optimalisasi lahan usaha } \\
\text { 2.Pengembangan } \\
\text { infrastruktur terutama } \\
\text { transportasi dan jaringan } \\
\text { jalan } \\
\text { 3.Pengembangan daya } \\
\text { saing usaha }\end{array}$ & $\begin{array}{l}\text { 1.Penguatan usaha } \\
\text { 2. Pengembangan } \\
\text { kewirausahaan } \\
\text { 3. Pendampingan usaha }\end{array}$ \\
\hline
\end{tabular}

Sumber: Data Primer, diolah. 


\section{Kerajinan Logam}

Tabel 1.3. Matriks Kombinasi Strategi Komoditas Kerajinan Logam

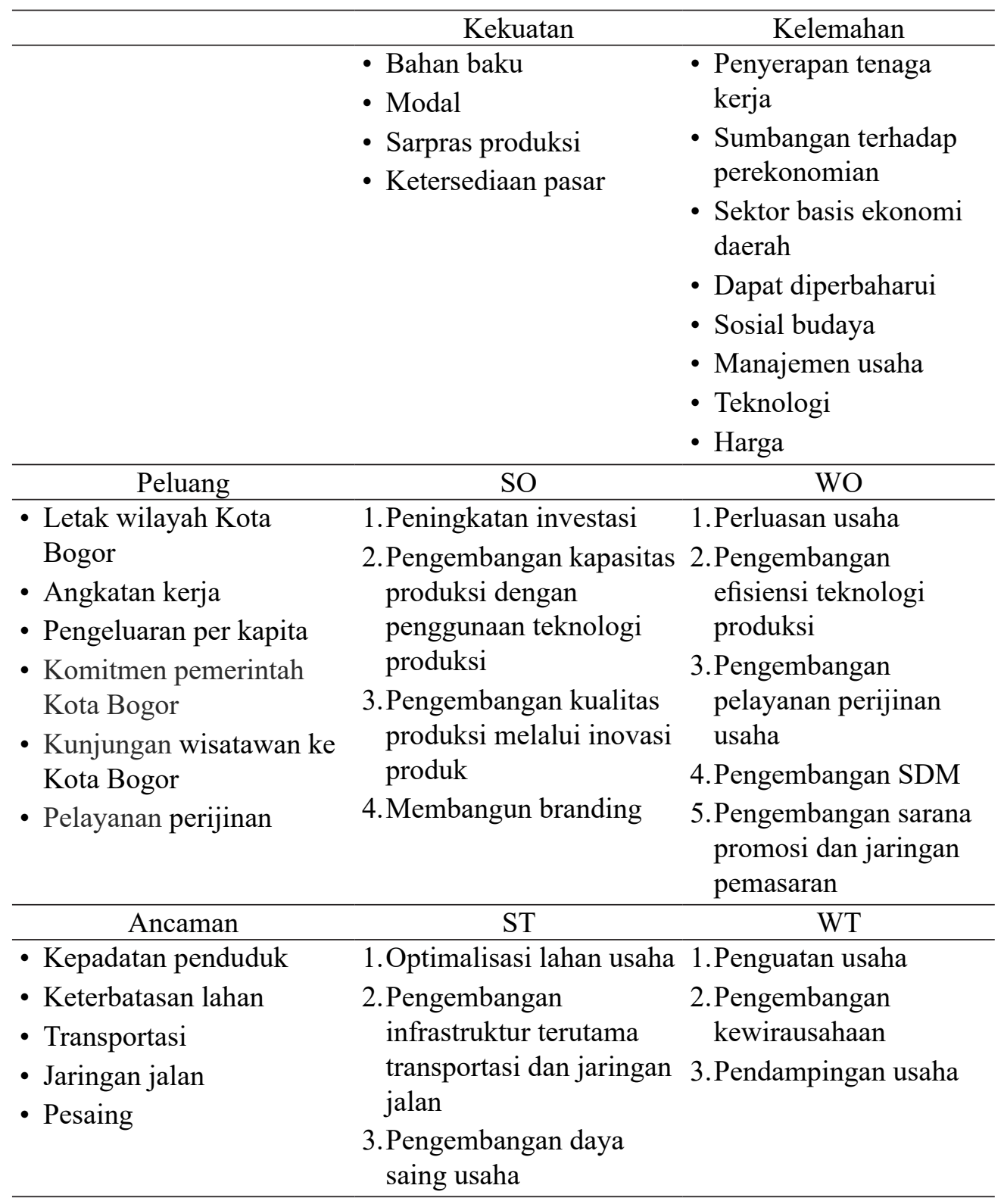

Sumber: Data Primer, diolah. 


\section{Kerajinan Batik}

Tabel 1.4. Matriks Kombinasi Strategi Komoditas Kerajinan Batik

\begin{tabular}{|c|c|c|}
\hline & Kekuatan & Kelemahan \\
\hline & $\begin{array}{l}\text { - Dapat diperbaharui } \\
\text { - Bahan baku } \\
\text { - Sarpras produksi } \\
\text { - Ketersediaan pasar }\end{array}$ & $\begin{array}{l}\text { - Penyerapan tenaga } \\
\text { kerja } \\
\text { - Sumbangan terhadap } \\
\text { perekonomian } \\
\text { - Sektor basis ekonomi } \\
\text { daerah } \\
\text { - Sosial budaya } \\
\text { - Manajemen usaha } \\
\text { - Modal } \\
\text { - Teknologi } \\
\text { - Harga }\end{array}$ \\
\hline Peluang & SO & WO \\
\hline $\begin{array}{l}\text { - Letak wilayah Kota } \\
\text { Bogor } \\
\text { - Angkatan kerja } \\
\text { - Pengeluaran per kapita } \\
\text { - Komitmen pemerintah } \\
\text { Kota Bogor } \\
\text { - Kunjungan wisatawan ke } \\
\text { Kota Bogor } \\
\text { - Pelayanan perijinan }\end{array}$ & $\begin{array}{l}\text { 1.Pengembangan kapasitas } \\
\text { produksi } \\
\text { 2.Pengembangan kualitas } \\
\text { produksi melalui inovasi } \\
\text { 3.Pengembangan usaha } \\
\text { secara kerkelanjutan } \\
\text { 4.Perlindungan hak paten }\end{array}$ & $\begin{array}{l}\text { 1.Perluasan Usaha } \\
\text { 2.Pengembangan } \\
\text { teknologi produksi } \\
\text { 3.Pengembangan } \\
\text { pelayanan perijinan } \\
\text { usaha } \\
\text { 4.Pengembangan SDM } \\
\text { 5. Pengembangan sarana } \\
\text { promosi dan jaringan } \\
\text { pemasaran }\end{array}$ \\
\hline Ancaman & ST & WT \\
\hline $\begin{array}{l}\text { - Kepadatan penduduk } \\
\text { - Keterbatasan lahan } \\
\text { - Transportasi } \\
\text { - Jaringan jalan } \\
\text { - Pesaing }\end{array}$ & $\begin{array}{l}\text { 1.Optimalisasi lahan usaha } \\
\text { 2.Pengembangan } \\
\text { infrastruktur terutama } \\
\text { transportasi dan jaringan } \\
\text { jalan } \\
\text { 3.Pengembangan daya } \\
\text { saing usaha }\end{array}$ & $\begin{array}{l}\text { 1.Penguatan Usaha } \\
\text { 2.Pengembangan } \\
\text { kewirausahaan } \\
\text { 3.Pendampingan usaha }\end{array}$ \\
\hline
\end{tabular}

Sumber: Data Primer, diolah 


\section{Industri Karet}

Tabel 1.5. Matriks Kombinasi Strategi Komoditas Alas Kaki

\begin{tabular}{|c|c|c|}
\hline & Kekuatan & Kelemahan \\
\hline & $\begin{array}{l}\text { - Bahan baku } \\
\text { - Sarpras produksi }\end{array}$ & $\begin{array}{l}\text { - Penyerapan tenaga } \\
\text { kerja } \\
\text { - Sumbangan terhadap } \\
\text { perekonomian } \\
\text { - Sektor basis ekonomi } \\
\text { daerah } \\
\text { - Dapat diperbaharui } \\
\text { - Sosial budaya } \\
\text { - Manajemen usaha } \\
\text { - Modal } \\
\text { - Teknologi. } \\
\text { - Ketersediaan pasar } \\
\text { - Harga }\end{array}$ \\
\hline Peluang & SO & WO \\
\hline - Letak wilayah Kota & 1.Pengembangan kapasitas & 1.Perluasan usaha \\
\hline Bogor & Produksi. & 2.Pengembangan \\
\hline - Angkatan kerja & 2.Pengembangan kualitas & teknologi produksi \\
\hline - Pengeluaran per kapita & produk & 3.Pengembangan \\
\hline $\begin{array}{l}\text { - Komitmen pemerintah } \\
\text { Kota Bogor }\end{array}$ & $\begin{array}{l}\text { 3.Pengembangan } \\
\text { sertifikasi hak paten }\end{array}$ & $\begin{array}{l}\text { pelayanan perijinan } \\
\text { usaha }\end{array}$ \\
\hline $\begin{array}{l}\text { - Kunjungan wisatawan ke } \\
\text { Kota Bogor }\end{array}$ & & $\begin{array}{l}\text { 4.Pengembangan akses } \\
\text { permodalan }\end{array}$ \\
\hline • Pelayanan perijinan & & 5.Pengembangan SDM \\
\hline & & $\begin{array}{l}\text { 6. Pengembangan sarana } \\
\text { promosi dan jaringan } \\
\text { pemasaran }\end{array}$ \\
\hline Ancaman & ST & WT \\
\hline - Kepadatan penduduk & 1.Optimalisasi lahan usaha & 1.Penguatan usaha \\
\hline - Keterbatasan lahan & $\begin{array}{l}\text { 2.Pengembangan } \\
\text { infrastruktur terutama }\end{array}$ & $\begin{array}{l}\text { 2.Pengembangan } \\
\text { kewirausahaan }\end{array}$ \\
\hline - Jaringan jalan & $\begin{array}{l}\text { transportasi dan jaringan } \\
\text { jalan }\end{array}$ & 3.Pendampingan usaha \\
\hline & $\begin{array}{l}\text { 3.Pengembangan daya } \\
\text { saing usaha. }\end{array}$ & \\
\hline
\end{tabular}

Sumber: Data Primer, diolah. 


\section{E. KESIMPULAN DAN SARAN}

1. Terdapat lima industri yang berpotensi untuk dijadikan tumpuan dalam pengembangan ekonomi lokal, yaitu 1. kuliner khas dengan komoditas ayam ungkep; 2. fesyen dengan komoditas pakaian; 3. Kerajinan dengn komoditas kerajinan loga; 4. kerajinan batik dengan komoditas batik t, dan karet dengan komoditas alas kaki.

2. Hasil perhitungan tipologi klassen yang telah di lakukan menyatakan bahwa sektor industri olahan yang ada di kota bogor yang didalamnya terdapat lima komoditas lokal kota Bogor termasuk ke dalam sektor yang potensial untuk di kembangkan karena mempunyai potensi yang besar untuk di kembangkan, dan bukan merupakan sektor basis Daerah

3. Kota Bogor mempunyai potensi ekonomi lokal yang besar yang mampu memberikan dampak yang besar bagi perekonomian daerah karena mampu mendorong perekonomian masyarakat hingga lapisan paling bawah, karena kelima komoditas usaha lokal di kota bogor mampu membuka lowongan pekerjaan ti bagi masyarakat di sekitarnya dengan rata - rata tenaga kerja yang di ambil 3 - 7 tenaga kerja.

4. Melalui analisis SWOT atas kelima komoditas tersebut, maka terdapat 15 strategi pengembangan yaitu 1. Pengembangan kapasitas produksi; 2. Pengembangan kualitas dan teknologi produksi; 3. Pengembangan akses permodalan; 4. Pengembangan SDM; 5. Membangun branding; 6. Perluasan Usaha; 7. Pengembangan efisiensi teknologi produksi; 8. Pengembangan pelayanan perijinan usaha; 9. Pengembangan sarana promosi dan jaringan pemasaran; 10 . Optimalisasi lahan usaha; 11. Pengembangan infrastruktur terutama transportasi dan jaringan jalan; 12. Pengembangan daya saing usaha; 13. Penguatan Usaha; 14. Pengembangan kewirausahaan; dan 15. Pendampingan usaha

\section{DAFTAR PUSTAKA}

Ainin, S., F. Praveen, S. Moghavvemi, dan N. I. Jaafar. (2015). "Faktors influencing the use of sosial media by SMEs and its performance outcomes." Industrial Management \& Data Systems, 115(3): 570-588.

Bala Subrahmanya, M. H. (2009). "Nature and strategy of product innovations in SMEs: A case study-based comparative perspective of Japan and India." Innovation: Management, Policy \& Practice, 11(1): 104-113.

Basrowi dan Suwandi (2008). Memahami Penelitian Kualitatif. Jakarta: PT Rineka Cipta.

Badan Pusat Statistik Kota Bogor. (2018). Kota Bogor Dalam Angka 2018.

Badan Pusat Statistik Kota Bogor. (2018). Produk Domestik Regional Bruto Kota Bogor Berdasarkan Lapangan Usaha Tahun 2013-2017. 
Rangkuti, F. (2008). Analisis SWOT Teknik Membedah Kasus Bisnis. Jakarta: PT Gramedia Pustaka Utama.

Republik Indonesia. (2014). Permendagri No. 9 Tahun 2014 tentang Produk Unggulan Daerah

Strauss, A. dan Corbin, J. (2009), Basic of Qualitative Research (terjemehan). Yogyakarta: Pustaka Pelajar.

Scase, R., dan R. Goffee. (1980). The Real World of the Business Owner. London: Croom Helm.

Westerlund, M., dan S. Svahn. (2008). "A relationship value perspective of social capital in networks of SMEs.” Industrial Marketing Management, 37(5): 492-501.

Niskha Sandriana, Abdul Hakim, Choirul Saleh (2015), Strategi Pengembangan Produk Unggulan Daerah Berbasis Klaster Di Kota Malang, Jurnal REFORMASI ISSN 2088-7469 (Paper) ISSN 2407-6864 (Online) Vol. 5, No. 1, 2015

Blakely, E.J. (1989). Planning Local Economic Development: Theory and Practice. London: Sage Publication. 